\title{
Helplessness among University Students: An Empirical Study Based on a Modified Framework of Implicit Personality Theories
}

\author{
Albert Ziegler ${ }^{1, *}$, Svenja Bedenlier ${ }^{2}$, Michaela Gläser-Zikuda ${ }^{2}$, Bärbel Kopp ${ }^{2}$ and Marion Händel ${ }^{1}$ (D) \\ 1 Department of Psychology, University of Erlangen-Nuremberg, Regensburger Str. 160, \\ 90478 Nürnberg, Germany; marion.haendel@fau.de \\ 2 Department of Education, University of Erlangen-Nuremberg, Dr-Mack-Straße 77, 90762 Fürth, Germany; \\ svenja.bedenlier@ili.fau.de (S.B.); michaela.glaeser-zikuda@fau.de (M.G.-Z.); baerbel.kopp@fau.de (B.K.) \\ * Correspondence: albert.ziegler@fau.de
}

Citation: Ziegler, A.; Bedenlier, S.; Gläser-Zikuda, M.; Kopp, B.; Händel, M. Helplessness among University Students: An Empirical Study Based on a Modified Framework of Implicit Personality Theories. Educ. Sci. 2021, 11, 630. https://doi.org/10.3390/ educsci11100630

Academic Editor: Eleni Andreou

Received: 10 August 2021

Accepted: 24 September 2021

Published: 12 October 2021

Publisher's Note: MDPI stays neutral with regard to jurisdictional claims in published maps and institutional affiliations.

Copyright: (C) 2021 by the authors Licensee MDPI, Basel, Switzerland. This article is an open access article distributed under the terms and conditions of the Creative Commons Attribution (CC BY) license (https:// creativecommons.org/licenses/by/ $4.0 /)$.

\begin{abstract}
Due to the COVID-19 pandemic, and within a very short period of time, teaching in the 2020 summer term changed from predominantly on-site to online instruction. Students suddenly faced having to adapt their learning process to new demands for which they may have had both insufficient digital skills and a lack of learning resources. Such a situation carries the risk that a substantial number of students become helpless. The aim of our empirical study was to test a hybrid framework of helplessness that includes both objective causes of helplessness and students' subjective interpretations of them. Before lectures or courses began, students of a full-scale university were invited to participate in an online survey. The final sample consists of 1690 students. Results indicate that objective factors as well as their subjective interpretations contributed to the formation of helplessness.
\end{abstract}

Keywords: higher education; digital learning; COVID-19 pandemic; helplessness; implicit theories of personality

\section{Introduction}

Within the first months of 2020, governments around the world responded to the COVID-19 pandemic with a variety of different measures, including travel restrictions, curfews, and the closing of educational institutions [1,2]. By the 20th of March, Germany announced far-reaching measures to curb the COVID-19 pandemic. German universitieswhere our research takes place-completely switched to online courses.

Research has shown that the use of modern technologies in learning can have multiple positive effects on students [3-6]. Nonetheless, there are several reasons to assume that this rapid shift to online learning amidst a catastrophic event may have triggered the perception of helplessness in a significant cohort of university students [7]. A recent dependence on digital learning coupled with potential instances of helplessness among students is an opportunity to test theoretical assumptions about antecedents of helplessness in higher education. In this work, we will focus on the role of individual skills, learning resources, and implicit personality theories in the modifiability and stability of abilities. Our focus on these three factors is both theoretically grounded and based on pedagogical considerations.

Exposure to uncontrollable outcomes can bring about the phenomenon of learned helplessness, a state in which a person fails to take advantage of control, although the situation is objectively controllable [8-11]. Helplessness is defined as "hopelessness and resignation learned when a human or an animal perceives no control over repeated bad events" [12] (p. 56).

It is assumed that helplessness results in behavioral, motivational, emotional, and cognitive deficits [13]. Indeed, research has repeatedly shown that the perception of one's own helplessness is associated with numerous behavioral, personal, and social problems such as greater test anxiety [14-16]; negative emotions such as boredom [17]; maladaptive 
behavior types such as internalizing (e.g., withdrawal, depression) and externalizing problems (e.g., delinquent and aggressive behavior) [18-20]; perceiving tasks that require persistence as beyond one's reach [21,22]; lower achievements [23-25]; and burnout [26].

The scientific explanation of helplessness and its (negative) consequences is still not conclusive. This is in part, due to the fact that the term is not used uniformly in scientific discourse. Scholars sometimes make reference to the phenomenon of helplessness itself, to the theory of helplessness, or to both constructs [27]. However, there is another notable discrepancy in the use of the term, which is expressed, for example, in the definition of helplessness: "Helplessness is a state in which nothing a person opts to do affects what is happening. It is the quitting or the give up response that follows the conviction that whatever a person does doesn't matter" [28] (p. 426). A notable aspect of this definition is that it distinguishes an objective and a subjective side of helplessness. In the first sentence, an objective state is assumed and in the second sentence, a subjective reaction to it. The focus on the objective side dominated the initial phase of helplessness research, which investigated helpless behavior in animals. As its shortcomings became increasingly apparent, research interest in helplessness shifted markedly to the subjective side of interpreting objective conditions [29]. From an educational point of view, however, we consider both aspects as equally important, as we will explain below.

\subsection{Objective and Subjective Factors in the Explanation of Helplessness}

The original explanation for helplessness held that persons perceive outcomes independent of their behavior [8,29]. Moreover, the phenomenon of helplessness comprises more than the inability to produce certain outcomes [30]. Many researchers noted problems with such a sparse explanation [31-33]. For example, some people, far from becoming helpless, increased their efforts and improved their performance [34-36]. The central issue became then, the individual interpretation of the bad, uncontrollable event [37-41]. In the "attributional reformulation" of learned helplessness, it was claimed that inescapability and the perception of non-contingency were insufficient to produce helplessness. Rather, the explanations that subjects proposed for the causes of the non-contingency predicted the extent of helplessness [37,42].

Various studies have found a correlation between helplessness and the aforementioned attribution style $[19,33,43]$. Situations that favor external (causes by situational or external factors), global (across different contexts), and stable (consistent over time) attributions can cause helplessness [44]. It seems quite likely that the COVID-19 pandemic and the associated switch to digital learning could encourage such a helpless attribution pattern. The switch to digital instruction is due to the COVID-19 crisis (external); is not limited to a single session or class; and at the same time, affects all classes (global) over the entire semester and probably beyond (stable).

However, attributional reformulation was also criticized early on [41,45]. For example, it was questioned whether the dimensions of the select attributions are really the most significant to the emergence of helplessness. One line of development in the field of helplessness research literature sought to uncover further antecedents of helplessness, not least with the aim of better understanding interindividual differences. Indeed, many antecedents of helplessness are identifiable, including negative social expectations [46], motivational orientations [47], self-efficacy [48,49], maladaptive perfectionism [50], and frustration intolerance [51]. But these findings on antecedents did not change the basic pattern of explanation, according to which there must be mediating factors between the experience of non-contingency, inescapability, and helplessness. These mediating factors were supposed to give a person a sense of control. In fact, these antecedents are usually not understood as the mediators, but as the antecedents to these mediators. For example, high self-esteem should result in less susceptibility to helplessness, because high selfesteem tends to increase the tendency to attribute success to internal and stable factors, and failure to external and unstable factors [52]. However, there were also some exceptions to the localization of the antecedent effect after the effect of the mediating factor. For 
example, the mediating role of maladaptive perfectionism in the association between psychological control and learned helplessness [50]. Another line of development focused on the mediators themselves [30,53-58]. For example, in the attributional tradition, the interpretation of an event seems even more important than the event itself $[53,56]$. This is in contrast to approaches where the objective structure of events is important, but must be learned-either in the form of Bayesian learning, by way of generalizations about controllability [30], or via the reward prevalence [57]. The theoretical approach pursued in this work takes a middle position with regard to helplessness, in that both the subjective interpretation of events and objective aspects of reality are ascribed important roles. In addition, we recognize the importance of other antecedents that may influence the objective probability or the subjective assessment of producing an outcome.

We present our own approach not as a model of helplessness, as in our view, the complexity of helplessness with its various antecedents is still beyond the theoretical and methodological scope of introducing a model. Rather, we assert that an important step toward such a useful model to higher education is possible by developing a framework in the sense of a "network of linked concepts" [59] (p. 49).

\subsection{A Hybrid Framework of Helplessness}

The helplessness framework presented in this work can be considered a hybrid because it encompasses objective and subjective factors of helplessness. The objective factors refer to whether a person would, in principle, be able to achieve an outcome. It is assumed that two main factors are important toward that end: one's own competencies, as well as the resources that can be used to bring about an outcome.

Here, competence refers to the individual ability of a person to produce an outcome [60-65]. However, a person who cannot produce an outcome is not yet necessarily helpless. In fact, he or she might ask other people for help or decide to acquire the missing competences through learning. To assess the objective side of helplessness, therefore, it is important to know whether a person can activate further resources to produce the effect in the absence of their own competences [66]. These resources can be very diverse. Their absence can be interpreted as barriers to successful digital learning $[67,68]$.

On the subjective side, following the work of $[69,70]$, we propose an extended variant of Dweck's implicit personality theory of the origin of helpless reactions. Helpless reactions in the face of (repeated) failure are predominantly demonstrated by persons who subscribe to an entity theory as opposed to an incremental personality theory [54,71,72]. Persons who subscribe to an entity theory view individual abilities as stable, whereas persons who subscribe to an incremental theory see them as malleable.

Dweck has provided a lot of evidence that incremental theorists react more adaptively when facing failure [73-77]. However, building on [70], we believe that the focus on change and on the modifiability of deficits is insufficient. There are many well-established psychological constructs and theories that also assign a positive role to stability. For example, self-affirmation theory maintains that individuals are motivated to keep up an image of oneself that is able to control important and adaptive outcomes in life [78-80]. They engage in "identity-protective reasoning" [81-83] and actively seek verification of self-views that they consider to be important and central to the self $[84,85]$. This tendency to stabilize positive aspects of personality may point to the existence of an explicit theoretical component that functions within many influential constructs such as self-esteem [86-88], self-concept [89], self-regard [90,91], and self-definition [92]. Even in self-presentation, individuals seek to maintain positive impressions of the self in view of others [93]. In line with these approaches, [70] concluded that the focus on the modifiability of deficits is insufficient. They assumed that it is also important for individuals to believe that their own ability to produce outcomes remains stable and will not change with circumstances.

The hybrid framework of helplessness in educational settings was developed primarily under pedagogical considerations and is summarized in Figure 1. A distinction is made between objective factors (i.e., competencies and resources), their subjective interpretation 
(implicit theories of modifiability and stability), and different antecedents of objective and subjective factors.

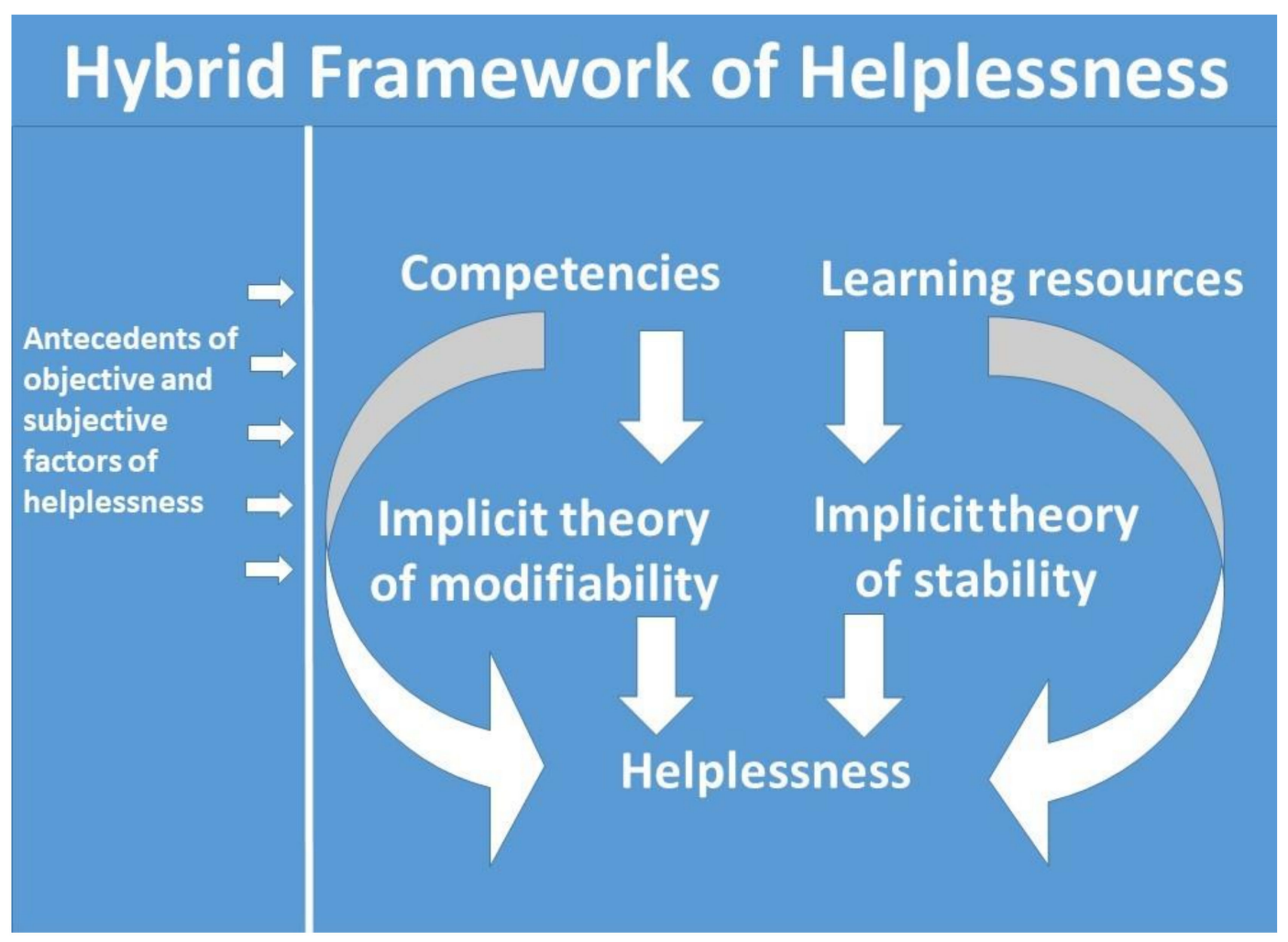

Figure 1. The proposed hybrid framework of helplessness with assumed direct influences and indirect influences of objective factors, mediated through their subjective interpretation of helplessness.

It is assumed that two objective factors can cause helplessness: a lack of competences and a lack of resources to produce desired outcomes in educational settings. In contrast to the original concept of the phenomenon of learned helplessness, actual helplessness is when an actual objectively existing control is not exercised [8,29]. As a result, this objective understanding of helplessness puts more emphasis on the need for help in pedagogical settings (see also [28]): the helpless are persons who, under normal learning conditions, are unable to produce objectively or subjectively (or both) required outcomes in pedagogical settings.

For pedagogical reasons, we consider the inclusion of the two objective factors in the hybrid framework to be useful. From an educator's point of view, it is important to know whether someone can achieve the outcome required in an educational setting by his or her own efforts, and with the available resources. If not, from the perspective of the educator, the person is helpless and needs active help to achieve the outcome. Therefore, helplessness in this hybrid framework is, above all, an educational construct that indicates the need for prevention or intervention.

Our hybrid framework of helplessness considers two subjective interpretations of objective circumstances: the stability of existing possibilities to produce an outcome, as well as the modifiability of yet-non-existing possibilities to produce an outcome.

Finally, antecedents beyond the four core concepts of competencies, learning resources, and the implicit theories of modifiability and stability were added to the hybrid framework of helplessness. There are three reasons for this. Firstly, it simply reflects the state of current research that a multitude of different antecedents of helplessness were discovered in research studies [46-51]. Secondly, that the objective and subjective factors postulated in the hybrid framework have numerous causes is also true. For example, an almost unmanageable abundance of antecedents of competencies was found in research. These 
first two reasons taken together indicate that the causal network, at the end of which lies helplessness, is far too complex to be reduced to a handful of factors in a framework or model. For an institution of higher education, however, a framework is important whether or not it allows reality to be represented in all its complexity. A framework must also be pedagogically useful. Therefore, we consider it a pragmatically justifiable decision to limit the number of factors in a framework, but at the same time to enable flexibility. This flexibility makes room for antecedents in the hybrid framework. The situation that arose in academia as a result of the COVID-19 pandemic is a prime example of the usefulness of this approach.

The sudden switch to teaching and online learning affected the entire pedagogical structure and organization, while also changing students' expectations towards higher education [94,95]. In a recent [96] report, it is stated that, "while this is a strong stress test for education systems, this is also an opportunity to develop alternative education opportunities" (p. 1). Indeed, numerous empirical studies confirm that universities face a significant modified antecedent condition with, in turn, presumed effects on the objective factors of the hybrid model and their subjective interpretation [97,98]. Presumably, this sudden switch influenced the role of student competences in the (virtual) learning process because digital skills are growing in importance alongside subject-related skills. At the same time, learning resources such as didactic educational capital shifted [99]. The limited experience of many lecturers with online teaching may have made it difficult for many students to achieve their learning goals. This is because their teaching often resembled more "emergency remote teaching" than thoroughly prepared online instruction [100].

Moreover, antecedents that potentially led to a change in the objective factors of the hybrid framework may subsequently lead to new subjective assessments. For example, in the face of this uncertain and makeshift online teaching, students may not have known for certain whether their-from their perspective-available competences and resources for online learning are sufficient in the context of this new situation or how well they can compensate for existing deficits in competences and resources for digital learning.

Emotional factors as another antecedent may have also influenced the assessments of the objective factors [71]. At the time of our study during the COVID-19 pandemic, 56\% of Germans between the ages of 18-29 years perceived their situation as stressful. In the overall population, $69 \%$ reported that the Corona virus was rather or even more frightening for them [101].

In summary, the concept of antecedents allows for a flexible consideration of whether the objective and subjective factors included in the hybrid framework of helplessness could be influenced in a way that would finally end in actual helplessness. Furthermore, from a pedagogical point of view, the antecedents can also be regarded as potential early indicators of helplessness. The identification of antecedents may signal an occasion to look for signs of emerging helplessness on the basis of the objective and subjective factors mentioned above and, if necessary, to intervene or take preventive measures.

\subsection{The Current Research}

During the lockdown caused by the COVID-19 pandemic, and just before the beginning of the 2020 summer semester, we conducted a study with students enrolled in a German university. Natural disasters and macro-crises can result in feelings of helplessness [102-104], especially when the situation is perceived as challenging [105] and personal autonomy is threatened [106,107]. In other words, students cannot simply escape the COVID-19 pandemic. Fear and stress about COVID-19 can cause strong emotional reactions which might eventually result in worsening chronic and mental health problems [108-110]. In this situation, the switch to digital learning at universities is another circumstance from which students cannot escape, and that represents another risk factor for the development of helplessness. "Helplessness arises when, despite the functioning of the cognitive system and awareness of circumstances and feelings, an individual is unable to access practical knowledge. As a result, the subject becomes a victim of one's own inability 
to perform, or act, in the real world" [111] (p. 948). With regard to the COVID-19 pandemic and the associated shift to digital learning, this indicates an increased sense of helplessness among various groups of students. Students may now lack the ability to achieve their learning goals. Furthermore, the ability to achieve learning goals is particularly limited in the case of students with a low academic achievement level and students with low digital skills. This leads to the first two hypotheses regarding the helplessness of the students in our study:

Hypothesis 1 (H1). Students with a lower academic achievement level have a higher risk of developing helplessness.

Hypothesis 2 (H2). Students with lower digital skills have a higher risk of developing helplessness.

However, according to the hybrid framework, there is at least one other significant objective risk factor: the lack of digital learning resources. Non-contingency due to a lack of ability to produce an effect alone does not cause helplessness. Similarly, the lack of digital skills should not necessarily trigger helplessness [34]. Helplessness also depends on what resources a person has available and can activate toward transforming non-contingency into contingency [112].

The idea that scholars should distinguish between internal and external resources goes back to the integrated model [56]. For example, the authors categorize work-related factors such as task difficulty and structure as internal environment simulators, whereas technology, social values, economic and political-legal conditions were listed as external environment simulators. Since then, a wide range of resources were identified, including economic, organizational, working conditions, and motivation [113]. In this paper, we will use the educational and learning capital model [99] to capture learning resources, as the model was developed specifically to capture endogenous and exogenous learning resources.

Hypothesis 3 (H3). Students with fewer endogenous and exogenous digital learning resources have an increased risk of developing helplessness.

As well as objective factors, the subjective interpretation of the objective factors is postulated as a possible risk factor for the development of helplessness. Regarding the special situation of digital learning, the implicit theories of the modifiability and stability of the digital skills and resources necessary for learning success play a central role. This leads to a total of four hypotheses on the meditative effect of implicit theories.

Hypothesis 4 (H4). The influence of digital skills on the development of helplessness is mediated by the implicit theory of the stability of abilities.

Hypothesis $\mathbf{5}$ (H5). The influence of digital resources on the development of helplessness is mediated by the implicit theory of the stability of abilities.

Hypothesis 6 (H6). The influence of digital skills on the development of helplessness is mediated by the implicit theory of the modifiability of abilities.

Hypothesis 7 (H7). The influence of digital resources on the development of helplessness is mediated by the implicit theory of the modifiability of abilities.

\section{Method and Materials}

The study reports on the first of three measurements within an ongoing longitudinal study of the 2020 summer semester. It took place as an online survey to which all students at a full university were invited. Participation in the study was voluntary and compliance with data protection was assured. 


\subsection{Procedure}

In the week before the start of the official lecture period, all students enrolled at the university were invited via an e-mail correspondence from the Vice President of Education to take part in a survey on the general conditions of digital teaching (via a survey access link). Participation in the survey took place via the Questback platform and was activated for 10 days. To reduce questionnaire length in the study, a simple form of a multi-matrix design was implemented [114]. As the first step, all students provided personal details and answered questions about previous academic achievement and digital literacy. In a second step, they were randomly assigned to three groups, each of which was presented with a further block of questionnaire scales. Here, we report the results of the group that filled out the helplessness questionnaire.

\subsection{Instruments}

The students were asked about their gender and age. Regarding university variables, study semester and faculty enrollment were also assessed.

Academic achievement level was assessed by the current average grade. Please note that higher scores indicate lower achievements.

To assess the four core concepts of competencies, learning resources, and implicit theories of modifiability and stability, established questionnaire scales were used and adapted to the current semester of digital learning. The individual items were answered on a six-level Likert scale ranging from 1 "not at all correct" to 6 "completely correct".

Digital skills were measured with eight items of two subscales from the Digital Readiness for Academic Engagement questionnaire (DRAE) [115]. The items focused on the application of digital tools (sample item: "I can use software or apps on a computer or mobile device") as well as on information-sharing behavior (sample item: "I can interact with fellow students using real-time communication media, e.g., video conferencing tools or messenger services").

Digital learning resources were assessed with a shortened version of the Questionnaire of Educational and Learning Capital (QELC) [116], which was adapted to the field of digital learning. Detailed descriptions and data from the original surveys for these and the scales described hereafter can be found in the references given below. While the original questionnaire contained 50 items, the short version contained 20 items. Systematic research had shown that even shortened and domain-specific scales have good reliability $[117,118]$. A sample item for the original QELC cultural educational resources reads, "In my social environment, learning is considered to be very important." The reformulated item read, "In my social environment, digital learning is considered to be very important."

Stability beliefs were measured with a shortened, four item version of a scale developed by [70]. A sample item reads, "After I have learned something, I don't forget how to apply it." Higher scores on this scale indicate more pronounced stability beliefs.

Modifiability beliefs were measured with a shortened, four item version of a scale developed by [70]. A sample item is: "I can improve my skills." Higher scores on this scale indicate more pronounced modifiability beliefs.

The degree of helplessness was measured with a modified version of the helplessness scale [119]. The scale comprises six items with which helplessness is primarily operationalized in terms of an experienced loss of control. All items that were originally related to academic learning in general were reformulated for the specific learning situation of the upcoming summer semester. The original item, "Even if I try hard, I will not succeed," was changed to "Even if I try hard, I will not succeed in the coming summer semester."

\subsection{Sample}

Of about 38,500 students enrolled at the university, 5563 students (which corresponds to $15 \%$ of all students) took part in the survey, of which 1690 students filled out the helplessness questionnaire. In order to obtain an inventory that was as uninfluenced as possible, students who took part in the survey after the start of the official lecture period 
and who stated that they had already attended digital courses in the current semester were excluded from the data analysis (less than $1 \%$ of the respondents). In the current sample, $52 \%$ of the respondents were female, $33 \%$ male, $0.4 \%$ non-binary; $15 \%$ did not provide any information on gender. The participating students were on average 23.4 years old $(\mathrm{SD}=4.9)$ and were enrolled in their 4.8 semester $(\mathrm{SD}=2.8)$.

Table 1 shows the absolute and relative frequencies in the surveyed sample, as well as the respective share of the total university student population for classification purposes. The table indicates that students participated in the survey across all five faculties and that the participation distribution corresponds approximately with the distribution within the university (e.g., $13.5 \%$ of the participating students are enrolled at the Faculty of Sciences; $14.0 \%$ of the students of the full-scale university are enrolled in this faculty). Regarding the desired degree, the proportions are also comparable to the distribution within the total number of students.

Table 1. Sample separately reported by faculty and desired degree.

\begin{tabular}{cccc}
\hline Group of Students & Frequency & \% of Participating Students & $\begin{array}{c}\text { Relative Number of Students per } \\
\text { Faculty of All Students }\end{array}$ \\
\hline Faculty & & & \\
Faculty of Humanities, Social & 525 & 31.1 & 24.6 \\
Sciences, and Theology & 228 & 13.5 & 14.0 \\
Faculty of Sciences & 317 & 18.8 & 25.1 \\
Faculty of Business, & 410 & 24.3 & 26.0 \\
Economics, and Law & 207 & 12.2 & 10.3 \\
Faculty of Engineering & & & 39.6 \\
Faculty of Medicine & 665 & 39.3 & 24.4 \\
\hline Expected degree & 420 & 24.9 & 30.1 \\
Bachelor & 550 & 32.5 & 3.9 \\
Master & 24 & 1.4 & - \\
State exam & 16 & 0.9 & \\
Doctoral exam & Others & & \\
\hline
\end{tabular}

\subsection{Data Analysis}

Descriptive statistics are reported. Hypotheses 1-7 were analyzed by means of structural equation modeling, using the Mplus 7 [120]. First, we tested a model representing the hypothesized relations between students' achievement level, students' digital skills, students' digital learning resources, students' implicit theories of stability and modifiability, and students' perceived helplessness. Given an acceptable overall fit of the initial model, we specified and estimated a final model in which we omitted non-significant paths of the initial model.

Figure 2 displays the model with expected signs of the postulated relations. Student helplessness was modeled as dependent on students' achievement level, students' digital skills, students' digital learning resources, as well as students' implicit theories of stability and modifiability. In addition, students' implicit theories of stability and modifiability were modeled to depend on students' digital skills and students' digital learning resources. The residuals of students' achievement level, students' digital skills, and students' digital learning resources could covary freely, which was also true for students' implicit theories of stability and modifiability. 


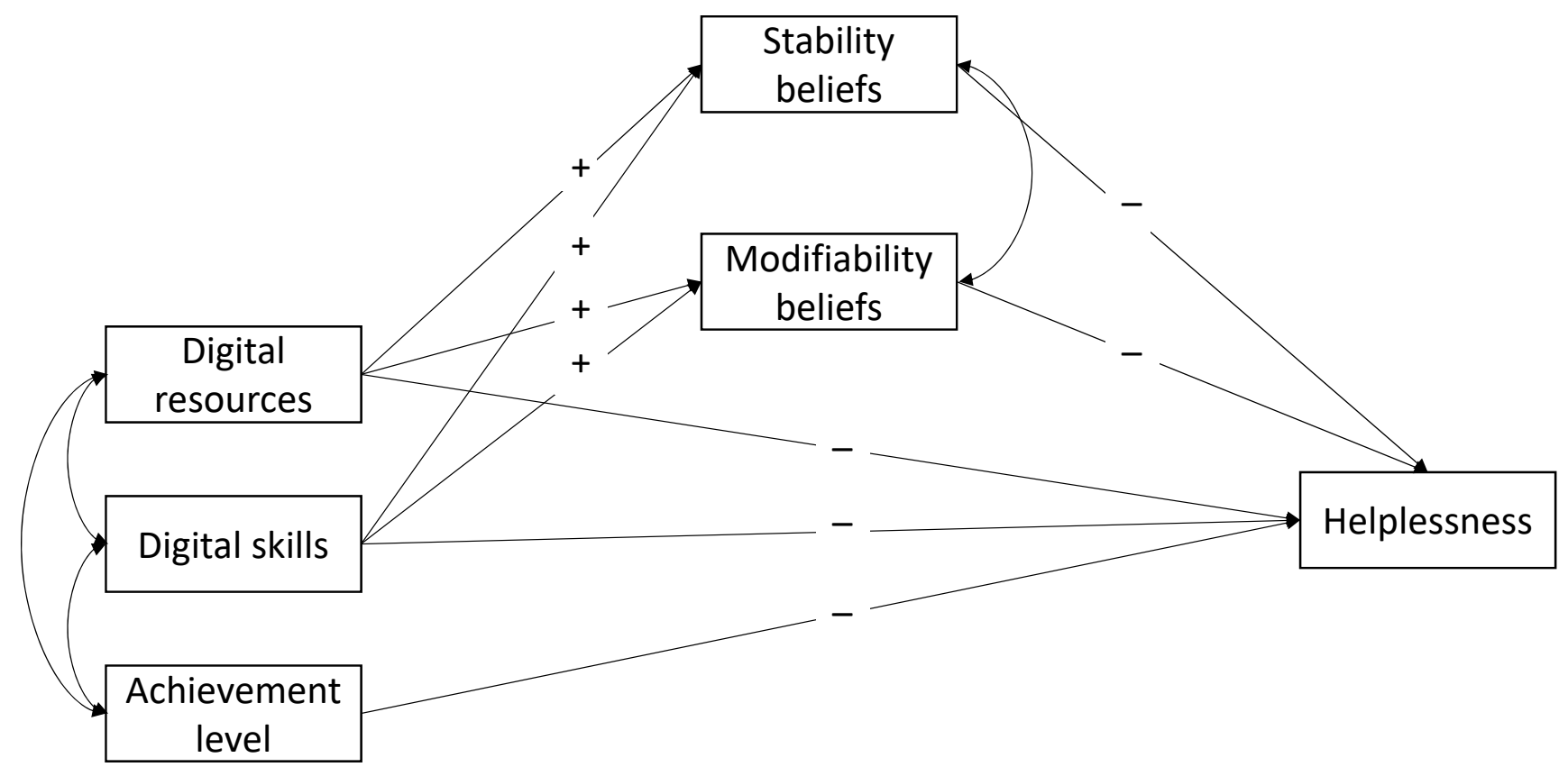

Figure 2. Theoretical model. Plus signs indicate to-be-expected positive path coefficients; minus signs indicate to-beexpected negative path coefficients.

The model fit was evaluated using the Comparative Fit Index (CFI), the root mean square error of approximation (RMSEA), and the standardized root mean squared residual (SRMR). A good (acceptable, respectively) model fit was inferred if the following cutoff values were met: CFI $\geq 0.95$, RMSEA $\leq 0.06$, SRMR $\leq 0.08$ [121]. Finally, we evaluated the fit of the final model in comparison to the fit of the initial model via an $\chi^{2}$ test comparing the two nested models.

\section{Results}

Table 2 provides descriptive statistics and correlations of the investigated variables. All scales were of sufficient internal consistency (Cronbach's $\alpha \mathrm{s} \geq 0.81$ ). All mean scores ranged from 1 to 6 . Furthermore, substantial correlations among stability and modifiability with the assumed predictor variables were detected. Hence, their interrelationship was further tested via a mediation model.

Table 2. Internal consistency, descriptive statistics and correlations of all variables.

\begin{tabular}{ccccccccc}
\hline Variable & $\boldsymbol{\alpha}$ & $\boldsymbol{M}$ & $\boldsymbol{S D}$ & $\mathbf{2}$ & $\mathbf{3}$ & $\mathbf{4}$ & $\mathbf{5}$ & $\mathbf{6}$ \\
\hline 1 Digital resources & 0.90 & 3.85 & 0.69 & 0.31 & 0.08 & 0.29 & 0.45 & -0.41 \\
2 Digital skills & 0.85 & 4.86 & 0.82 & & 0.05 & 0.15 & 0.30 & -0.19 \\
3 Achievement level & - & 2.18 & 0.68 & & & 0.03 & 0.10 & 0.41 \\
4 Stability beliefs & 0.88 & 3.68 & 0.92 & & & & 0.28 & -0.23 \\
5 Modifiability beliefs & 0.81 & 5.00 & 0.65 & & & & & -0.43 \\
6 Helplessness & 0.92 & 2.15 & 0.87 & & & & & \\
\hline
\end{tabular}

Note. $|\mathrm{r}| \geq 0.05: p \leq 0.05 ;|\mathrm{r}| \geq 0.08: p \leq 0.001$.

The overall model fit of the initial model was good, $\chi^{2}(2)=7.63, \mathrm{CFI}=0.995$, RMSEA $=0.041$, $\mathrm{SRMR}=0.013$. All path coefficients except the path of digital skills on helplessness were significant and in the hypothesized direction, all $|\beta| \mathrm{s} \geq 0.07, \mathrm{ps} \leq 0.01$. Thus, this path was removed from the initial model.

The final model also fit the data well, $\chi^{2}(3)=7.91, \mathrm{CFI}=0.996$, RMSEA $=0.030$, $\mathrm{SRMR}=0.013$. Figure 2 shows the estimated coefficients of the final model, which did not fit the data significantly worse than the initial model, Satorra-Bentler scaled chi-square difference test: $\Delta \chi^{2}(1)=0.13, p=0.71$. 
Direct effects on helplessness could be detected for digital learning resources as well as for student achievement level. The more endogenous and exogenous resources to which students can refer, the less helpless they feel. Similarly, students with higher grades feel less helpless. These results confirm hypotheses 1 and 2, whereas hypothesis 3 could not be confirmed: there was no significant direct path from digital skills to helplessness.

Furthermore, significant direct and indirect effects were found (cf., Table 3), and the meditation hypotheses (hypotheses 4-7) were confirmed. In detail, both digital skills as well as digital learning resources positively influenced implicit theories of stability and modifiability, which, in turn, were related negatively to helplessness. The strongest effects were found for the effect of digital learning resources on helplessness, mediated via students' modifiability beliefs (see Figure 3).

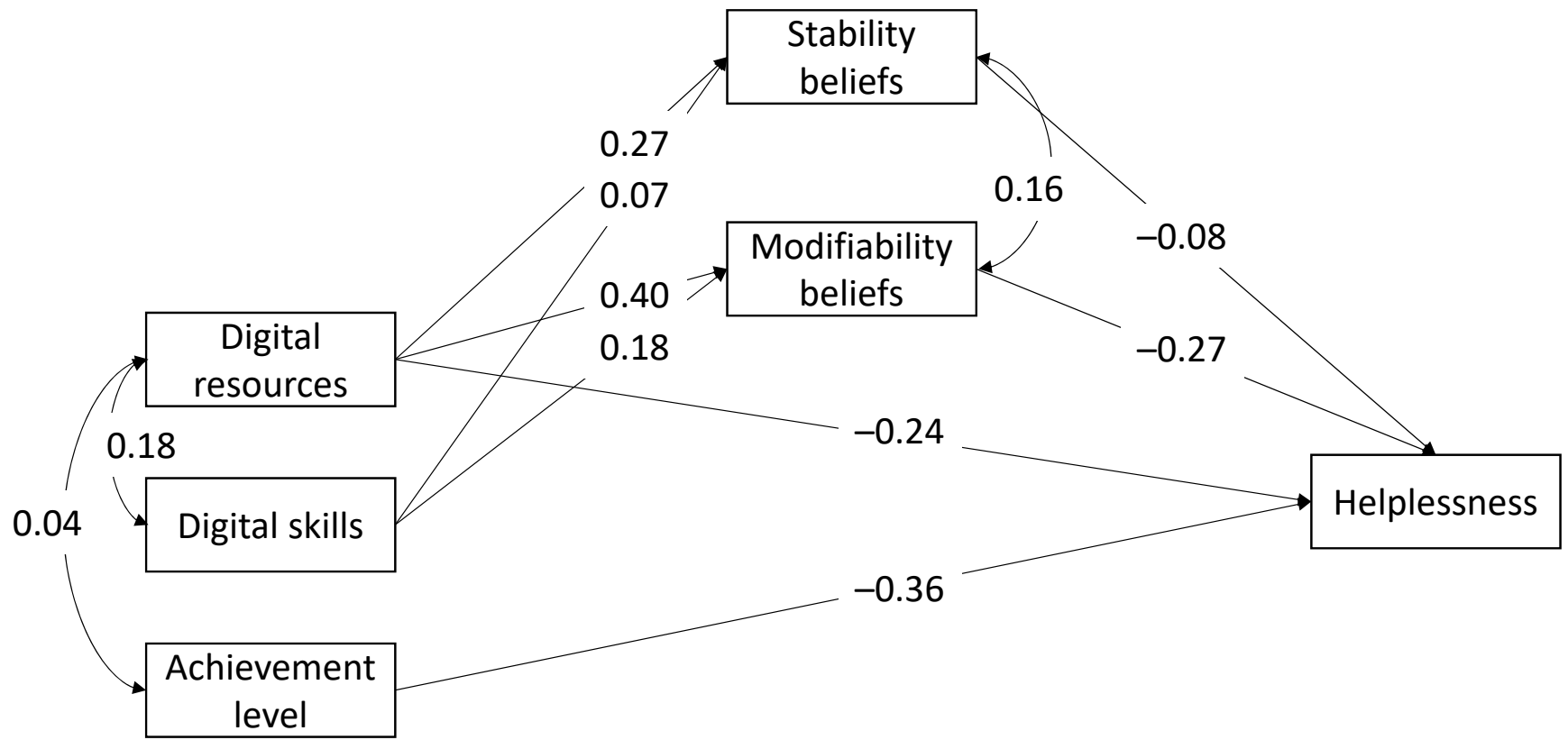

Figure 3. Standardized estimated coefficients of the final model. All coefficients are significant with $p \leq 0.001$.

Table 3. Standardized estimates for the direct and indirect effects of digital skills as well as digital learning resources on helplessness, mediated via students' implicit theories of stability and modifiability.

\begin{tabular}{ccc}
\hline Effects & Estimate & $S E$ \\
\hline Digital skills -> Helplessness & & \\
Total & -0.05 & 0.01 \\
Total indirect & -0.05 & 0.01 \\
Digital skills $>$ Stability -> Helplessness & -0.01 & 0.00 \\
Digital skills -> Modifiability -> Helplessness & -0.05 & 0.01 \\
\hline Digital learning resources -> Helplessness & \\
Total & -0.37 & 0.02 \\
Total indirect & -0.13 & 0.01 \\
Digital learning resources -> Stability -> Helplessness & -0.02 & 0.01 \\
Digital learning resources -> Modifiability -> Helplessness & -0.11 & 0.01 \\
Direct & -0.24 & 0.03 \\
\hline
\end{tabular}

\section{Discussion}

The starting point of our empirical study provided a unique opportunity to investigate helplessness that arose as a result of the COVID-19 pandemic. Due to the closure of universities, a switch to digital instruction was necessary. This suddenly required special digital skills and resources from students for successful digital learning. These are objectively 
available in varying degrees, whereby the extent to which they are personally available is presumably assessed differently by the students. We have described these as the objective and subjective factors of the causes of helplessness.

The proposed hybrid framework of helplessness is based on a broader understanding of helplessness: individuals are helpless if they cannot produce an outcome or if they believe that they cannot produce an outcome [28]. In our view, such an approach offers both conceptual advantages and practical benefits in the diagnosis and treatment of helplessness in natural, especially university settings.

The hybrid framework of helplessness focuses on two objective factors for academic success at university: first, the upcoming summer semester curriculum that now features competencies that include specific skills for digital learning; and second, the resources necessary for successful digital learning, such as IT equipment, bandwidth, social support, well-planned courses, etc. [113]. In the path analysis, evidence was found that these objective factors are important, as two out of three direct postulated paths to helplessness were statistically significant.

In the hybrid framework of helplessness, we further assumed that the subjective interpretation of objective factors can also play an important role in the development of helplessness. We assumed that implicit theories of the modifiability of deficits, but also of the stability of strengths, play a key role $[69,70]$. Indeed, path analysis showed that both implicit theories mediate the effects of digital skills and the effects of digital learning resources on helplessness.

Although a total of six out of seven postulated hypotheses could be confirmed in our study, it is not easy to draw a conclusion. Since the hybrid framework of helplessness includes elements of other models, the results of our study also confirm individual aspects of each of them. With objective models of helplessness $[30,57]$, the hybrid framework has in common the assumption that the objective probability of success predicts helplessness. This was the case for two of the three antecedents examined: academic achievement level and digital learning resources. In contrast, the results of the mediator analyses are consistent with the reformulated model assumption that subjective interpretation is important [37,42]. Our results support Dweck's approach [54,71,72] in that the strongest paths in the path model were mediated by the modifiability beliefs. The results also support that the stability theory is indicative of a mediator $[67,70]$. However, in addition to these numerous findings that are compatible with individual segments of established models, it is important to note that no model, including the hybrid framework of helplessness, could be fully confirmed.

Thus, one can cautiously conclude that more eclectic approaches should be tested in the future. This observation is all the more valid since even the hybrid framework of helplessness which contains both objective and subjective factors almost certainly do not cover the complexity of the emergence of helplessness. For example, many known risk factors of helplessness such as negative social expectations [46], motivational orientations [47], selfefficacy [48,49], maladaptive perfectionism [50], and frustration intolerance [51] are only mentioned vaguely as antecedents. So, what could our results mean for higher education in particular?

We would like the hybrid framework of helplessness to be understood as a pedagogicalpragmatic approach of higher education. Of course, it also claims to represent reality. It was developed in the awareness that helplessness is a complex phenomenon which, in our opinion, cannot be broken down to a few variables. A full understanding of all antecedents, boundary conditions, and processes is arguably, even beyond scientific reach. Nonetheless, helplessness is a very serious problem that is not just a performance impairment. It also carries significant consequences for mental health [29]. Therefore, in designing our hybrid framework of helplessness, we have essentially focused on what an institution like the university can contribute to prevent or reduce helplessness. We think that tenets of higher education need to be vigilant in three respects: objective and subjective factors of helplessness, as well as risk factors of helplessness-termed-as-antecedents in the hybrid framing of helplessness. 
Firstly, many risk factors for the development of helplessness are well-known and quite intuitive like low self-efficacy [48,49] or frustration intolerance [51]. Other risk factors are discernible including the sudden altering of learning requirements, as prescribed by the changes that occurred in response to the COVID-19 pandemic. Should universities see risk potential, they may wish to examine the objective and subjective factors contained in the hybrid framework.

Secondly, higher education institutions should always check for the possibility of students achieving learning success through their own efforts, whether by competences, learning resources, and the absence of learning barriers. Here, a first alarm signal for lecturers is certainly poor student performance.

Thirdly, implicit theories can be a risk factor if either the stability of one's own ability to produce certain outcomes is doubted or the modifiability of one's own deficits is questioned. They should always be given attention, when general risk factors and performance deficits are present. They can be examined in discussions with students or short questionnaires, for example. Such information may eventually lead to the taking of steps to stop the downward spiral triggered by helplessness in time.

Many measures of helplessness prevention and intervention were proposed in the literature and their effectiveness empirically confirmed (modeling, attributional retraining, etc.). We do not intend our proposal of a new hybrid framework to question the effectiveness of these measures. However, examining these measures from the perspective of our hybrid model might be instructive and allow for a more nuanced picture. For example, in presenting role models, more emphasis is usually placed on showing how they overcome failures, that is, the aspect of modifiability of deficits is emphasized more relative to the stability of one's strengths. Balancing both aspects and their interplay with the objective antecedents of helplessness opens up a broad field of applied research.

\section{Limitations}

Our study examined a hybrid framework of helplessness. Certainly not all potential causes of helplessness were covered. Other contributing causes could be, for example, the fear associated with the pandemic [101] or sensational coverage in the media, where metaphors surrounding keywords like "war" and "fight" were often employed. However, we suggested that such further causes can be flexibly integrated in a hybrid framework as antecedents.

For the reason of limited survey time, it was not possible to distinguish completely between subject-related and digital skills, and learning resources in the study. Although this was not exactly necessary in order to explore the hybrid framework of helplessness with regard to the transition to digital teaching, taking this distinction into account would have contributed to a more comprehensive examination of the framework as a whole.

At first glance, it may appear contradictory that objective factors of the causes of helplessness (digital skills and digital learning resources) were measured from the subjective perspective of the participants. However, the developers of the measuring instruments do claim to measure objective factors [115,116]. Moreover, at the time of the imposition of a curfew, it was hardly possible to collect data other than subjective data.

Finally, the parallel process structural equation modeling lack appropriate temporal sequencing for a stronger evaluation of our mediation assumptions. Therefore, any causal statements in general and assumptions of mediation can only be used alongside theoretical considerations as well as the pattern of correlations that is consistent with the hypotheses. Future studies should aim for such temporal sequencing and ideally, for multiple assessments during the course of the semester.

Author Contributions: Conceptualization, A.Z. and M.H.; methodology, A.Z. and M.H.; formal analysis, A.Z. and M.H.; investigation, B.K. and M.H.; writing-original draft preparation, A.Z. and M.H.; writing-review and editing, A.Z., B.K., M.G.-Z., M.H. and S.B.; visualization, A.Z.; supervision, A.Z.; project administration, M.H. All authors have read and agreed to the published version of the manuscript. 
Funding: This research received no external funding.

Institutional Review Board Statement: Ethical review and approval were waived for this study, as not mandatory for this questionnaire study in the given country.

Informed Consent Statement: Informed consent was obtained from all subjects involved in the study.

Data Availability Statement: The data presented in this study are available on request from the corresponding author.

Acknowledgments: We thank our student assistant Fabian Kratzer for support in data collection and data preparation. We thank our colleague Miguelina Nuñez for proof-reading the manuscript.

Conflicts of Interest: The authors declare no conflict of interest.

\section{References}

1. Bozkurt, A.; Jung, I.; Xiao, J.; Vladimirschi, V.; Schuwer, R.; Egorov, G.; Lambert, S.R.; Al-Freih, M.; Pete, J.; Olcott, D., Jr.; et al. A global outlook to the interruption of education due to COVID-19 pandemic: Navigating in a time of uncertainty and crisis. Asian J. Distance Educ. 2020, 15, 1-126. [CrossRef]

2. Cheng, C.; Barceló, J.; Hartnett, A.; Kubinec, R.; Messerschmidt, L. CoronaNet: A Dyadic Dataset of Government Responses to the COVID-19 Pandemic. Available online: https:/ / doi.org/10.31235/osf.io/dkvxy (accessed on 15 May 2020).

3. Bond, M.; Buntins, K.; Bedenlier, S.; Zawacki-Richter, O.; Kerres, M. Mapping research in student engagement and educational technology in higher education: A systematic evidence map. Int. J. Educ. Technol. High. Educ. 2020, 17, 2. [CrossRef]

4. Bull, P.H.; Keengwe, J. Advances in Educational Technologies and Instructional Design (AETID). Handbook of Research on Innovative Digital Practices to Engage Learners; IGI Global: Hershey, PA, USA, 2019. [CrossRef]

5. Dyson, B.; Vickers, K.; Turtle, J.; Cowan, S.; Tassone, A. Evaluating the use of Facebook to increase student engagement and understanding in lecture-based classes. High. Educ. 2015, 69, 303-313. [CrossRef]

6. Zhang, Y.A. Handbook of Mobile Teaching and Learning; Springer: Berlin, Germany, 2015.

7. Van Bavel, J.J.; Baicker, K.; Boggio, P.S.; Capraro, V.; Cichocka, A.; Cikara, M.; Crockett, M.J.; Crum, A.J.; Douglas, K.M.; Druckman, J.N.; et al. Using social and behavioural science to support COVID-19 pandemic response. Nat. Hum. Behav. 2020, 4, 460-471. [CrossRef]

8. Hiroto, D.S.; Seligman, M.E. Generality of learned helplessness in man. J. Pers. Soc. Psychol. 1975, 31, 311-327. [CrossRef]

9. Maier, S.F.; Watkins, L.R. Learned helplessness. In Encyclopedia of Psychology; Kazdin, A.E., Ed.; Oxford University Press: London, UK, 2000; Volume 4, pp. 505-508. [CrossRef]

10. Peterson, C.; Maier, S.F.; Seligman, M.E.P. Learned Helplessness: A Theory for the Age of Personal Control; Oxford University Press: New York, NY, USA, 1995.

11. Seligman, M.E.P. Learned helplessness. Annu. Rev. Med. 1972, 23, 407-412. [CrossRef]

12. Myers, D.G. Exploring Social Psychology, 3rd ed.; McGraw-Hill: New York, NY, USA, 2004.

13. Wu, S.; Tu, C.-C. The impact of learning self-efficacy on social support towards learned helplessness in China. Eurasia J. Math. Sci. 2019, 15, em1825. [CrossRef]

14. Cassady, J.C. The influence of cognitive test anxiety across the learning-testing cycle. Learn. Instr. 2004, 14, 569-592. [CrossRef]

15. Fincham, F.D.; Hokoda, A.; Sanders, R. Learned helplessness, test anxiety, and academic achievement: A longitudinal analysis. Child Dev. 1989, 60, 138-145. [CrossRef] [PubMed]

16. Raufelder, D.; Regner, N.; Wood, M.A. Test anxiety and learned helplessness is moderated by student perceptions of teacher motivational support. Educ. Psychol. 2018, 38, 54-74. [CrossRef]

17. Sharp, G.J.; Sharp, J.C.; Young, E. Academic boredom, engagement and the achievement of undergraduate students at university: A review and synthesis of relevant literature. Res. Pap. Educ. 2020, 35, 144-184. [CrossRef]

18. Klein, D.C.; Seligman, M.E. P Reversal of performance deficits and perceptual deficits in learned helplessness and depression. J. Abnorm. Psychol. 1976, 85, 11-26. [CrossRef]

19. Klein, D.C.; Fencil-Morse, E.; Seligman, M.E.P. Learned helplessness, depression, and the attribution of failure. Pers. Soc. Psychol. Rev. 1976, 33, 508-516. [CrossRef]

20. Sorrenti, L.; Spadaro, L.; Mafodda, A.V.; Scopelliti, G.; Orecchio, S.; Filippello, P. The predicting role of school learned helplessness in internalizing and externalizing problems. An exploratory study in students with specific learning disorder. Mediterr. J. Clin. Psychol. 2019, 7, 1-14. [CrossRef]

21. Abramson, L.Y.; Metalsky, G.I.; Alloy, L.B. Hopelessness depression: A theory-based subtype of depression. Psychol. Rev. 1989, 96, 358-372. [CrossRef]

22. Ames, C. Motivation: What teachers need to know. Teach. Coll. Rec. 1990, 91, 401-421.

23. Johnston-Wilder, S.; Goodall, J.; Almehrz, H. Overcoming statistical helplessness and developing statistical resilience in learners: An illustrative, collaborative, phenomenological study. Creat. Educ. 2018, 9, 1105-1122. [CrossRef]

24. Valas, H. Learned helplessness and psychological adjustment: Effects of age, gender and academic achievement. Scand. J. Educ. Res. 2001, 45, 71-90. [CrossRef] 
25. Valas, H. Learned helplessness and psychological adjustment II: Effects of learning disabilities and low achievement. Scand. J. Educ. Res. 2001, 45, 101-114. [CrossRef]

26. Maslach, C.; Jackson, S.E. Burnout in health professions: A social psychological analysis. In Social Psychology of Health and Illness; Sanders, G., Suls, J., Eds.; Erlbaum: Hillsdale, NJ, USA, 1982; pp. 227-251.

27. Overmier, J.B.; Molet, M. Learned helplessness. In Encyclopedia of Animal Cognition and Behavior; Vonk, J., Shackelford, T., Eds.; Springer: Cham, Switzerland, 2017. [CrossRef]

28. Nuvvula, S. Learned helplessness. Contemp. Clin. Dent. 2016, 7, 426-427. [CrossRef]

29. Maier, S.F.; Seligman, M.E.P. Learned helplessness at fifty: Insights from neuroscience. Psychol. Rev. 2016, 123, 349-367. [CrossRef] [PubMed]

30. Lieder, F.; Goodman, N.D.; Huys, Q.J.M. Learned helplessness and generalization. In Proceedings of the 35th Annual Conference of the Cognitive Science Society; Knauff, M., Pauen, M., Sebanz, N., Wachsmuth, I., Eds.; Cognitive Science Society: Austin, TX, USA, 2013; pp. 900-905.

31. Beevers, C.G.; Keitner, G.I.; Ryan, C.E.; Miller, I.W. Cognitive predictors of symptom return following depression treatment. J. Abnorm. Psychol. 2003, 112, 488-496. [CrossRef]

32. Hiver, P. Attractor states. In Motivational Dynamics in Language Learning; Dörnyei, Z., Henry, A., MacIntyre, P.D., Eds.; Multilingual Matters: Bristol, UK, 2014; pp. 20-28.

33. Miller, I.W.; Norman, W.H. Learned helplessness in humans: A review and attribution-theory model. Psychol. Bull. 1979, 86, 93-118. [CrossRef]

34. Roth, S.; Bootzin, R.R. The effects of experimentally induced expectancies of external control: An investigation of learned helplessness. J. Pers. Soc. Psychol. 1974, 29, 253-264. [CrossRef]

35. Roth, S.; Kubal, L. Effects of noncontingent reinforcement on tasks of differing importance: Facilitation and learned helplessness. J. Pers. Soc. Psychol. 1975, 32, 680-691. [CrossRef]

36. Tennen, H.; Eller, S.J. Attributional components of learned helplessness and facilitation. J. Pers. Soc. Psychol. 1977, 35, $265-271$. [CrossRef]

37. Abramson, L.Y.; Seligman, M.E.P.; Teasdale, I. Learned helplessness in humans: Critique and reformulation. J. Abnorm. Psychol. 1978, 87, 49-59. [CrossRef]

38. Dweck, C.S.; Wortman, C.B. Learned helplessness, anxiety, and achievement motivation: Neglected parallels in cognitive, affective, and coping responses. In Achievement, Stress, and Anxiety; Krohne, H.W., Laux, L., Eds.; Hemisphere: Washington, DC, USA, 1982; pp. 93-125.

39. Feist, J.; Feist, G.J. Theories of Personality; McGraw Hill: Boston, MA, USA, 2002.

40. Mohanty, A.; Pradhan, R.K.; Jena, L.K. Learned helplessness and socialization: A reflective analysis. Psychology 2015, 6, 885-895. [CrossRef]

41. Wortman, C.B.; Dintzer, L. Is an attributional analysis of the learned helplessness phenomenon viable? A critique of the Abramson-Seligman-Teasdale reformulation. J. Abnorm. Psychol. 1978, 87, 75-90. [CrossRef]

42. Alloy, L.B.; Peterson, C.; Abramson, L.Y.; Seligman, M.E.P. Attributional style and the generality of learned helplessness. J. Pers. Soc. Psychol. 1984, 46, 681-687. [CrossRef]

43. Zemore, R.; Johansen, L.J. Depression, helplessness, and failure attributions. Can. J. Behav. Sci. 1980, 12, 167-174. [CrossRef]

44. Weiner, B. An Attributional Theory of Motivation and Emotion; Springer: New York, NY, USA, 1986.

45. Frankel, A.; Snyder, M.L. Poor performance following unsolvable problems: Learned helplessness or egotism? J. Pers. Soc. Psychol. 1978, 36, 1415-1423. [CrossRef]

46. Pi, L.; Yan, Z.R. The influence of teacher expectation on learned helplessness in mathematics learning. J. Math. Educ. 2010, 19, 44-47.

47. Diener, C.I.; Dweck, C.S. An analysis of learned helplessness: II. The processing of success. J. Pers. Soc. Psychol. 1980, 39, 940-952. [CrossRef] [PubMed]

48. Putwain, D.W.; Symes, W. The perceived value of maths and academic self-efficacy in the appraisal of fear appeals used prior to a high-stakes test as threatening or challenging. Soc. Psychol. Educ. 2014, 17, 229-248. [CrossRef]

49. Sorrenti, L.; Filippello, P.; Costa, S.; Buzzai, C. A psychometric examination of the Learned Helplessness Questionnaire in a sample of Italian school students. Psychol. Sch. 2015, 52, 923-941. [CrossRef]

50. Filippello, P.; Larcan, R.; Sorrenti, L.; Buzzai, C.; Orecchio, S.; Costa, S. The mediating role of maladaptive perfectionism in the association between psychological control and learned helplessness. Improv. Sch. 2017, 20, 113-126. [CrossRef]

51. Filippello, P.; Harrington, N.; Costa, S.; Buzzai, C.; Sorrenti, L. Perceived parental psychological control and school learned helplessness: The role of frustration intolerance as a mediator factor. Sch. Psychol. Int. 2018, 39, 360-377. [CrossRef]

52. Tubre, T.C.; Collins, J.M. A meta-analysis of the relationships between role ambiguity, role conflict, and job performance. J. Manag. 2000, 26, 155-169.

53. Carlson, D.S.; Kacmar, K.M. Learned helplessness as a predictor of employee outcomes: An applied model. Hum. Resour. Manag. Rev. 1994, 4, 235-256. [CrossRef]

54. Dweck, C.S. Mindset: The New Psychology of Success; Random House: New York, NY, USA, 2006.

55. Dweck, C.S.; Yeager, D.S. Mindsets: A view from two eras. Perspect. Psychol. Sci. 2019, 14, 481-496. [CrossRef] [PubMed] 
56. Martinko, M.J.; Gardner, W.L. Learned helplessness: An alternative explanation on performance deficits. Acad. Manag. Rev. 1982, 7, 195-204. [CrossRef]

57. Teodorescu, K.; Erev, I. Learned helplessness and learned prevalence: Exploring the causal relations among perceived controllability, reward prevalence, and exploration. Psychol. Sci. 2014, 25, 1861-1869. [CrossRef] [PubMed]

58. Thomas, D.A. Channeling the River: Using Positive Psychology to Prevent Cultural Helplessness, as Applied to African-American Law Students. Unpublished Doctoral Dissertation. 2016. Available online: http://repository.upenn.edu/mapp_capstone/96 (accessed on 21 July 2021).

59. Jabareen, Y. Building a conceptual framework: Philosophy, definitions, and procedure. Int. J. Qual. Methods 2009, 8, 49-62. [CrossRef]

60. Alqurashi, E. Self-efficacy in online learning environments: A literature review. Contemp. Issues Educ. Res. 2016, 9, 45-52. [CrossRef]

61. Chang, C.C. Alteration of influencing factors of continued intentions to use e-learning for different degrees of adult online participation. IRRODL 2015, 16, 33-61. [CrossRef]

62. Cheung, R.; Vogel, D. Predicting user acceptance of collaborative technologies: An extension of the technology acceptance model for e-learning. Comput. Educ. 2013, 63, 160-175. [CrossRef]

63. Sawang, S.; Newton, C.; Jamieson, K. Increasing learners' satisfaction/intention to adopt more e-learning. Educ. Train. 2013, 55, 83-105. [CrossRef]

64. Taipjutorus, W. The Relationship between Learner Control and Online Learning Self-Efficacy. Doctoral Dissertation, Massey University, Manawatu Campus, Palmerston North, New Zealand, 2014.

65. Tang, Y.; Tseng, H.W. Distance learners' self-efficacy and information literacy skills. J. Acad. Libr. 2013, 39, 517-521. [CrossRef]

66. Heckhausen, J.; Heckhausen, H. Motivation and action: Introduction and overview. In Motivation and Action; Heckhausen, J., Heckhausen, H., Eds.; Springer: Cham, Switzerland, 2018; pp. 1-14.

67. Ali, S.; Uppal, M.A.; Gulliver, S. A conceptual framework highlighting e-learning implementation barriers. Inf. Technol. People 2018, 31, 156-180. [CrossRef]

68. Muilenburg, L.Y.; Berge, Z.L. Student barriers to online learning: A factor analytic study. Distance Educ. 2005, 26, 29-48. [CrossRef]

69. Ziegler, A.; Stoeger, H. Research on a modified framework of implicit personality theories. Learn. Individ. Differ. 2010, 20, 318-326. [CrossRef]

70. Ziegler, A.; Fidelman, M.; Reutlinger, M.; Vialle, W.; Stoeger, H. Implicit personality theories on the modifiability and stability of the action repertoire as a meaningful framework for individual motivation: A cross-cultural study. High Abil. Stud. 2010, 21, 147-164. [CrossRef]

71. Dweck, C.S. Self-Theories: Their Role in Motivation, Personality and Development; Psychology Press: Philadelphia, PA, USA, 1999.

72. Dweck, C.S.; Chiu, C.Y.; Hong, Y.Y. Implicit theories and their role in judgments and reactions: A word from two perspectives. Psychol. Inq. 1995, 6, 267-285. [CrossRef]

73. Blackwell, L.A.; Trzesniewski, K.H.; Dweck, C.S. Theories of intelligence and achievement across the junior high school transition: A longitudinal study and an intervention. Child Dev. 2007, 78, 246-263. [CrossRef] [PubMed]

74. Dweck, C.S.; Leggett, E.L. A social-cognitive approach to motivation and personality. Psychol. Rev. 1988, 95, 256-273. [CrossRef]

75. Dweck, C.S.; Grant, H. Self-theories, goals, and meaning. In Handbook of Motivation Science; Shah, J.Y., Gardner, W.L., Eds.; The Guilford Press: New York, NY, USA, 2008; pp. 405-416.

76. Dweck, C.S.; Master, A. Self-theories motivate self-regulated learning. In Motivation and Self-Regulated Learning: Theory, Research, and Applications; Schunk, D.H., Zimmerman, B.J., Eds.; Lawrence Erlbaum Associates Publishers: New York, NY, USA, 2008; pp. 31-51.

77. Molden, D.C.; Dweck, C.S. Finding "Meaning" in psychology: A lay theories approach to self-regulation, social perception, and social development. Am. Psychol. 2006, 61, 192-203. [CrossRef]

78. Cohen, G.L.; Sherman, D.K. The psychology of change: Self-affirmation and social psychological intervention. Annu. Rev. Psychol. 2014, 65, 333-371. [CrossRef]

79. Sherman, D.K. Self-affirmation: Understanding the effects. Soc. Personal. Psychol. Compass 2013, 7, 834-845. [CrossRef]

80. SHERMAN, D.K.; COHEN, G.L. The psychology of self-defense: Self-affirmation theory. In Advances in Experimental Social Psychology: Advances in Experimental Social Psychology; Zanna, M.P., Ed.; Elsevier Academic Press: Amsterdam, The Netherlands, 2006; Volume 38, pp. 183-242. [CrossRef]

81. Branscombe, N.R.; Ellemers, N.; Spears, R.; Doosje, B. The context and content of the social identity threat. In Social Identity: Context, Commitment, Content; Ellemers, N., Spears, R., Doosje, B., Eds.; Blackwell: Oxford, UK, 1999; pp. $35-58$.

82. Kahan, D.M. Misconceptions, Misinformation, and the Logic of Identity-Protective Cognition. Cultural Cognition Project. Working Paper Series 164 Yale Law School Public Law research paper 605; Yale Law \& Economics Research Paper 575.2017. Available online: http:/ / doi.org/10.2139/ssrn.3046603 (accessed on 21 July 2021).

83. Kahan, D.M. The expressive rationality of inaccurate perceptions. Behav. Brain Sci. 2017, 40, 26-28. [CrossRef]

84. Chen, S.; Chen, K.Y.; Shaw, L. Self-verification motives at the collective level of self-definition. J. Pers. Soc. Psychol. 2004, 86, 77-94. [CrossRef] [PubMed]

85. Swann, W.B.; Rentfrow, P.J.; Guinn, J.S. Self-verification: The search for coherence. In Handbook of Self and Identity; Leary, M.R., Tangney, J.P., Eds.; Guilford Press: New York, NY, USA, 2003; pp. 367-383. 
86. Brown, J.D. Self-esteem and self-evaluations: Feeling is believing. In Psychological Perspectives on the Self; Suls, J., Ed.; Erlbaum Press: Hillsdale, NJ, USA, 1993; Volume 4, pp. 27-58.

87. Brown, J.D.; Mankowski, T.A. Self-esteem, mood, and self-evaluation: Changes in mood and the way you see you. J. Pers. Soc. Psychol. 1993, 64, 421-430. [CrossRef] [PubMed]

88. Harter, S. Causes and consequences of low self-esteem in children and adolescents. In Plenum Series in Social/Clinical Psychology. Self-Esteem: The Puzzle of Low Self-Regard; Baumeister, R.F., Ed.; Plenum Press: Boston, MA, USA, 1993; pp. 87-116. [CrossRef]

89. Baumeister, R.F. Identity: Cultural Change and the Struggle for Self; Oxford University Press: New York, NY, USA, 1986.

90. Rogers, C.R. On Personal Power. Inner Strength and Its Revolutionary Impact; Delacorte: New York, NY, USA, 1977.

91. Rogers, C.R. A way of Being; Houghton Mifflin: Boston, MA, USA, 1980.

92. Wicklund, R.A.; Gollwitzer, P.M. Symbolic Self-Completion; Erlbaum: Hillsdale, NJ, USA, 1982.

93. Schlenker, B.R. Self-presentation. In Handbook of Self and Identity; In Leary, M.R., Tangney, J.P., Eds.; Guilford: New York, NY, USA, 2003; pp. 492-518.

94. Marinoni, G.; van't Land, H.; Jensen, T. The Impact of COVID-19 on Higher Education around the World. IAU Global Survey Report. 2020. Available online: https://www.iau-aiu.net/IAU-releases-Global-Survey-Report-on-Impact-of-Covid-19-inHigher-Education (accessed on 21 July 2021).

95. Bhagat, S.; Kim, D.J. Higher education amidst COVID-19: Challenges and silver lining. Inf. Syst. Manag. 2020, 37, 366-371. [CrossRef]

96. OECD. Education Responses to COVID-19: Embracing Digital Learning and Online Collaboration. 2020. Available online: https: / / read.oecd-ilibrary.org/view / ?ref=120_120544-8ksud7oaj2\&title=Education_responses_to_Covid19_Embracing_ digital_learning_and_online_collaboration (accessed on 21 July 2021).

97. Cicha, K.; Rizun, M.; Rutecka, P.; Strzelecki, A. COVID-19 and higher education: First-year students' expectations toward distance learning. Sustainability 2021, 13, 1889. [CrossRef]

98. Garcia, A.; Powell, G.B.; Arnold, D.; Ibarra, L.; Pietrucha, M.; Thorson, M.L.; Verhelle, A.; Wade, N.B.; Webb, S. Learned helplessness and mental health issues related to distance learning due to COVID-19. In Proceedings of the CHI EA '21: Extended Abstracts of the 2021 CHI Conference on Human Factors in Computing Systems, Yokohama, Japan, 8-13 May 2021; Volume 480, pp. 1-6. [CrossRef]

99. Ziegler, A.; Baker, J. Talent development as adaption: The role of educational and learning capital. In Exceptionality in East-Asia: Explorations in the Actiotope Model of Giftedness; Phillipson, S., Stoeger, H., Ziegler, A., Eds.; Routledge: London, UK, 2013; pp. 18-39.

100. Hodges, C.; Moore, S.; Lockee, B.; Trust, T.; Bond, A. The Difference between Emergency Remote Teaching and Online Learning. Educause Review. 2020. Available online: https:/ / er.educause.edu/articles/2020/3/the-difference-between-emergency-remoteteaching-and-online-learning (accessed on 21 July 2021).

101. COSMO. COVID-19 Snapshot Monitoring (COSMO). Available online: https://projekte.uni-erfurt.de/cosmo2020/cosmoanalysis.html (accessed on 15 June 2020).

102. Bohannon, L.; Clapsaddle, S.; McCollum, D. Responding to College students who exhibit adverse manifestations of stress and trauma in the college classroom. Forum Int. Res. Educ. 2019, 5, 66-78. [CrossRef]

103. Fritsche, I.; Moya, M.; Bukowski, M.; Jugert, P.; Lemus, S.; Decker, O.; Valor-Segura, I.; Navarro-Carrillo, G. The great recession and group-based control: Converting personal helplessness into social class in-group trust and collective action. J. Soc. Issues 2017, 73, 117-137. [CrossRef]

104. Heitkamp, K.L. Learned Helplessness, Welfare, and the Poverty Cycle; Greenhaven Publishing: New York, NY, USA, 2019.

105. McKean, K.J. Academic helplessness: Applying learned helplessness theory to undergraduates who give up when faced with academic setbacks. Coll. Stud. J. 1994, 28, 456-462.

106. Ashforth, B.E. The experience of powerlessness in organizations. Organ. Behav. Hum. Decis. Process. 1989, 43, 207-242. [CrossRef]

107. Ashforth, B.E.; Saks, A.M. Personal control in organizations: A longitudinal investigation with newcomers. Hum. Relat. 2000, 53, 311-339. [CrossRef]

108. Ahorsu, D.K.; Lin, C.Y.; Imani, V.; Saffari, M.; Griffiths, M.D.; Pakpour, A.H. The fear of COVID-19 scale: Development and initial validation. Int. J. Ment. Health Addict. 2020. [CrossRef]

109. National Center for Immunization and Respiratory Diseases, Coronavirus Disease. 2019. Available online: https://www.cdc. gov / coronavirus/2019-ncov / daily-life-coping/managing-stress-anxiety.html (accessed on 19 May 2020).

110. Zhang, Y.; Ma, Z.F. Impact of the COVID-19 pandemic on mental health and quality of life among local residents in Liaoning Province, China: A cross-sectional study. Int. J. Environ. Res. Public Health 2020, 17, 2381. [CrossRef]

111. Arieli, A.; Ataria, Y. Helplessness: The inability to know-that you don't know-how. Philos. Psychol. 2018, 31, 948-968. [CrossRef]

112. Costello, C.G. A critical review of Seligman's laboratory experiments on learned helplessness and depression in humans. $J$. Abnorm. Psychol. 1978, 87, 21-31. [CrossRef] [PubMed]

113. Palmer, I.; Dunford, R.; Akin, G. Managing Organizational Change. A Multiple Perspectives Approach, 2nd ed.; McGraw-Hill Publishing: Boston, MA, USA, 2009.

114. Smits, N.; Vorst, H.C.M. Reducing the length of questionnaires through structurally incomplete designs: An illustration. Learn. Individ. Differ. 2007, 17, 25-34. [CrossRef] 
115. Hong, A.J.; Kim, H.J. College students' digital readiness for academic engagement (DRAE) scale: Scale development and validation. Asia-Pac. Educ. Res. 2018, 27, 303-312. [CrossRef]

116. Vladut, A.; Liu, Q.; Leana-Tascilar, M.; Vialle, W.; Ziegler, A. A cross-cultural validation study of the questionnaire of educational and learning capital (QELC) in China, Germany and Turkey. Psychol. Test Assess. Model. 2013, 55, 462-478.

117. Reutlinger, M.; Pfeiffer, W.; Stoeger, H.; Vialle, W.; Ziegler, A. Domain-specificity of educational and learning capital: A study with musical talents. Front. Psychol. 2021. [CrossRef]

118. Ziegler, A.; Debatin, T.; Stoeger, H. Learning resources and talent development from a systemic point of view. Ann. N. Y. Acad. Sci 2019, 1445, 39-51. [CrossRef]

119. Ziegler, A.; Dresel, M.; Schober, B.; Stoeger, H. Ulm Motivational Test Battery (UMTB): Documentation of Items and Scales. Ulm Educational Psychological Research Report. 2005. Available online: https:/ /opus.bibliothek.uni-augsburg.de/opus4/frontdoor/ index/index/docId/41194 (accessed on 30 September 2021).

120. Muthén, L.K.; Muthén, B.O. Mplus User's Guide; Muthén \& Muthén: Los Angeles, CA, USA, 2007.

121. Hu, L.-t.; Bentler, P.M. Cutoff criteria for fit indexes in covariance structure analysis: Conventional criteria versus new alternatives. Struct. Equ. Mode 1999, 6, 1-55. [CrossRef] 